\title{
Financial Inclusion and its Impacts on Business Growth: A Comparative Analysis between Male and Female Entrepreneurs in Lagos State, Nigeria
}

\author{
Adijat Olubukola Olateju \\ Faculty of Social Sciences, Department of Economics, Lagos State \\ University, Ojo, Lagos, Nigeria
}

Doi: 10.19044/elp.v5no3a1

URL:http://dx.doi.org/10.19044/elp.v5no3a1

\begin{abstract}
Entrepreneurial activity is an important business activity, especially in developing countries where high level of poverty and inadequate job opportunities are still more prevalent. For entrepreneurs to ensure continuity in their business, the issue of business growth/expansion is of significant importance. This paper focuses on examining the effect of microcredit programme on the business growth of the beneficiary from the gender's perspective in a Cowries Microfinance Bank's (CMB) credit programme in Lagos, Nigeria. A systematic sampling technique was used to select a sample of 191 male entrepreneurs and 359 female entrepreneurs from the study bank. The data were analysed through a Propensity Score Matching (PSM). The results of the Average Treatment Effect on the Treated, obtained from the PSM analysis, indicate that the microcredit loan programme has a positive impact on the profit of both male and female entrepreneurs in the study area. Therefore, financial inclusion, through access to microfinance bank credit, has the potential of enhancing growth in the business of entrepreneurs. It is, thus, recommended that more focus should be given to microfinance banks. This is because it has the potential to enhance the business growth of the entrepreneurs in the study area.
\end{abstract}

Keywords: Financial Inclusion, Entrepreneurs, Propensity Score Matching (PSM), Credit programme.

\section{Introduction}

Nigeria's financial exclusion for adult is one of the highest in Africa and this stood at $46.3 \%$ as at $2011(\mathrm{CBN}, 2012)$. According to the CBN in 2012 , a total of 39.2 million $(46.3 \%$ ) of the total adult population, which stood at 84.1 million, are inaccessible to financial services. Also, in a recent survey by EFinA (2016) among some selected countries (South Africa, Madagascar, 
Togo, Zambia, Rwanda, Ghana, and Kenya), Nigeria still has the highest percentage of financially excluded adult which stood at $41.6 \%$. In terms of gender, $46.6 \%$ of adult female are financially excluded, while $36.8 \%$ of adult male are financially excluded (EFinA, 2016).

In view of this, Nigeria has initiated many financial inclusion strategies through the CBN. The apex bank in its efforts to address the high financial exclusion and to reduce it to $20 \%$ by the year 2020 , and also in accordance with the Maya declaration, has formulated a financial inclusion strategy that is channeled through simplified risk-based framework, national financial literacy framework, consumer protection framework, mobile payment system and cashless policy, established linkages, and the introduction of credit enhancement schemes and programme.

It should, however, be noted that for any economy that needs to increase its GDP growth, enjoy some levels of economic development, and thus maintain a sustainable growth and development in the business of the entrepreneurs, the issue of business growth (in terms of additional outlet or change in the status/size of the business firm from micro business to smallscale enterprises or medium scale enterprises) is very vital. Thus, this will help to ensure continuity in the business, increase employment, and reduce poverty.

However, capital which is one of the essential factors of production is one of the impediments to business growth and development which entrepreneurs often faced in most developing countries. Consequently, the little available capital needs to be utilized effectively and efficiently so that the growth of the business can be achieved. Entrepreneurs in Nigeria, like in some developing countries, still derive most of their sources of capital through borrowing from banks, especially microfinance banks. This is because most microfinance banks often require lesser collateral securities when compared to conventional banks. In addition, government in Nigeria has recently instructed microfinance banks to focus their lending activities more on entrepreneurs (CBN, 2012). Given this, this study strives to examine the impact of microcredit loan on the business growth of entrepreneurs by making a comparison between men entrepreneurs and women entrepreneurs in Lagos State, Nigeria. Many studies have often looked at the effect of microcredit access on the business growth of entrepreneurs. This is without disaggregating their data regarding the gender of the beneficiary of the loan programme. Some studies that looked at the gender aspect often based their analysis on women alone. However, this study has found out that men also play an active role in entrepreneurial activities in Nigeria, owing to the high unemployment rate and high rate of poverty.

In Nigeria, unlike some developing countries where most of the enterprise's businesses are done by women, the situation is entirely different as both men and women often engage in microenterprises businesses. 
Nevertheless, the number of women involving in this activity outweighs that of men. However, the difference is not too noticeable when compared to some developing countries. Thus, this study makes a comparative analysis between women and men entrepreneurs in order to assess the impact of microcredit programme on the business growth of the loan beneficiaries based on their gender. The profit earned by the entrepreneurs is used to measure growth in the business of entrepreneurs as used in some studies to measure business growth (Idowu \& Oyeleye, 2012; Wang, 2013; Laetitia, Shukla \& Luyanda, 2015).

Furthermore, a number of studies have looked at the financial inclusion at the macro level. The objective of this study is to examine the impact of financial inclusion through access to credit at the micro level based on the business growth of entrepreneurs. Hence, this is with specific emphasis on the gender of the participants in the credit programme.

The rest of this paper is divided into four sections. The next section sequel to this introductory section deals with some literature review on the impact of microcredit on business growth. Section three of the paper deals with the methodology employed by the study. The fourth Section presents the result, findings, and discussion of the study. Finally, the last section which is Section five provides the conclusion, recommendation, and some suggestions that may be useful for further research.

\section{Literature Review}

Despite many empirical studies on the impact of microfinance on business growth (Idowu \& Oyeleye, 2012; Ngugi \& kerongo, 2014; Babagana, 2010; Olusanya, Sufiani \& Temi, 2014; Laetitia, Shukla \& Luyanda, 2015), limited evidence still exist in this area of studies in terms of gender. This is because most studies often look at the impact generally without disaggregating the sample size into male and female. On the other hand, the few ones that are gender specific often focus on women. This is because women are believed to be the major clients of microfinance banks. Also, Myoux and Harti (2009) emphasized that little research has been recorded on the gender impact of financial services for men. In this section, this study reviewed some of the general literature on the impact of microcredit on the business growth of microenterprises. In addition to this, some few empirical studies that are gender specific were also reviewed.

Some of the non-gender specific studies are found in Idowu and Oyeleye (2012) who used a foster Greer Thurbecke Matching Framework analysis and partial correlation in analyzing the impact of microfinance banks on poverty alleviation in some selected local government areas in Oyo State, Nigeria. The study found that the profit and asset acquisition of the 
respondents are positively and significantly affected by access to microcredit in the study area.

Ngugi and kerongo (2014) found in their study of the effect of microfinancing on the growth of small and micro-enterprises in Mombasa County, Kenya, a positive effect of the loan on the business activities in the study area. Similarly, Wang (2013) identified the important role played by microfinance on the revenue and profit growth of small and medium enterprises (SMEs) in the study area. In the same vein, positive effect has also been found on the growth of small enterprises (Babagana, 2010; Olusanya, Sufiani \& Temi, 2014).

Furthermore, in a study in Rwanda, it was found that access to microcredit has helped in the beneficiaries' business performance in terms of increase in their capital profit, growth in the size of the business, and expansion (Laetitia, Shukla \& Luyanda, 2015). However, the authors emphasized on the entrepreneur's skills as a complementary factor to credit facility, that could help to enhance business growth. Johnson, Copestake and Bhalotral (2001) found in their impact assessment study of microcredit in Zambia a significant and higher growth on the profit of those who accessed the second loan cycle. Wang (2012) found in a study in China a positive effect of microfinance on the revenue and profit growth of SMEs in the study area. The author also identified the important role played by microfinance on the revenue and profit growth of small and medium enterprises (SMEs). In a study in Eastern Uganda, Wilfred, et al. (2016) found a positive impact of microfinance on SMEs in terms of growth in their businesses, capital, and stock accumulation.

Similarly, Yadessa, Jina and Akessa (2015) found that micro-financing schemes have been positively added to the development of small-scale enterprises and enhanced entrepreneurial attitude in Jimma Town, Oromia, Ethiopia. Also, Ferdousi (2015) in his study found a positive impact of access to loan on entrepreneurs business. Nevertheless, the author cautioned that less innovation in business may hinder this positive impact. As a result, he recommended that microcredit loan should be associated with proper business skills, information, and technologies. This makes it possible for the loan to be utilized effectively in order for the loan beneficiaries to enjoy the full benefit of the loan.

In spite of the insensitive nature of most studies on the gender aspect of the impact of microcredit on business growth, however, some few studies still exist that are gender specific. Among these studies is the study of Gichuki, Mulu-mutuku, and kinithua (2014) that assessed the performance of womenowned enterprises access to credit in a village in Kenya. In the study, they found that access to credit by women in the study area has a positive impact on the net profit and capital of small micro enterprises. 
Similarly, Ike (2013) found in a study in Enugu State, Nigeria, a positive impact of microfinance services on the business performance of the loan beneficiaries' women entrepreneurs through the increase in their income. Also, Rathirance and Semassinghe (2016) found that access to credit has enhanced the business performance of women in Sri Lanka by increasing the income/profit of the beneficiaries.

Michelle (2014) stated that at the early stage of the business, the impact of microcredit on women's business activities is positive; on the other hand, for men, the impact is negative both at the early stage and at the later stage of their business.

\section{Methodology}

\section{i) Area of Study}

The study was conducted in Lagos State, Nigeria. Lagos State was preferred because of its high business activities and high number of microfinance and microenterprises. Hence, this is in contradiction with its high poverty level. Cowries Microfinance Bank was selected from other microfinance bank because the bank is affiliated with Lagos State Microfinance Institution (LASMI).

ii) Data

A total of 550 data were collected through a systematic sampling technique. This data compose of 191 male entrepreneurs and 359 female entrepreneurs.

\section{iii) Model Specification and Analysis}

Various measurements were used in the literature to measure business growth. Some of these measurements are profit, asset, expansion in business, number of workers employed etc. However, this study used the profit earned by the entrepreneurs after the collection of the loan as used by some studies in the literature (Idowu \& Oyeleye, 2012; Wang, 2013; Laetitia, Shukla \& Luyanda, 2015). Based on this, the model for this study is given as:

$\mathrm{G}=\mathrm{a}_{0}+\mathrm{a}_{1} \mathrm{X}_{\mathrm{i}}+\mathrm{a}_{2} \mathrm{~A}+\mu$

$$
\mathrm{G}=\mathrm{F}(\mathrm{X}, \mathrm{A})
$$

Where

$\mathrm{G}$ represents growth in the business of entrepreneurs

ao represents the constant term

$\mathrm{X}_{\mathrm{i}}$ represents vectors of household characteristics

A represents access to the microcredit which is given as 1 and 0 otherwise $\mathrm{a}_{1}$ and $\mathrm{a}_{2}$ are the parameters to be estimated $\mu$ represents the error term

To analyse the model, Propensity Matching Score (PSM) technique was employed by the study. PSM is the conditional probability of participating in a programme/treatment by taking into consideration some pre-treatment characteristics of the participants. The PSM matches the treatment observation 
with the control observations that are similar or same in character. Therefore, this is done in order to eliminate the self-selection bias which is often common in observational studies.

Therefore, the PSM compares the impact of access to microcredit programme on the business growth of the treated male entrepreneurs with their control group (counterfactual) in the credit programme. Also, for the female entrepreneurs, PSM compares the impact of access to microcredit programme on the growth of the treated female entrepreneurs with their control group. Therefore, for this study, we matched the participant men/women entrepreneurs based on their propensity score using the probit model. Thus, the propensity score is given as: $\mathrm{P}(\mathrm{x})=\operatorname{prob}(\mathrm{y}=\mathrm{i} \mid \mathrm{x})=\mathrm{E}(\mathrm{y} \mid \mathrm{x})$ Where $\mathrm{y}=$ Dependent variable (outcome) $\mathrm{X}=$ Independent variable (characteristics of the respondents)

In observational studies like this study, where the observation is not randomly selected due to some self-selection bias (which could arise from non-random programme placement or individual self selecting into the programe), the PSM analysis result is based on the Average Treatment Effect on the treated (ATT). The essence of ATT is that it takes care of the selection bias between the control and the treated observation (Beker \& Ichino, 2002). The ATT result is obtained by subtracting from the outcomes of the treated observation the outcome of the treated observation as if they had been treated. Therefore, ATT is given as:

$\mathrm{ATT}=\mathrm{E}\left(\mathrm{y}_{1} \mid \mathrm{x}_{1} \mathrm{D}=1\right)-\mathrm{E}\left(\mathrm{y}_{0} \mid \mathrm{x}_{1} \mathrm{D}-1\right)$

From the equation above, the counterfactual is the second part of the equation on the right-hand size. This counterfactual is the observable characteristic of the respondents that needs to be estimated. Therefore, E $\left(\mathrm{y}_{1} \mid \mathrm{x}_{1} \quad \mathrm{D}=1\right)$ is the expected outcome of women/men entrepreneurs involvement in the credit programme on their business growth, while $\mathrm{E}$ ( $\mathrm{y}_{0} \mid \mathrm{x}_{1}$ D- 1) is the expected outcome of women/men involved in the credit programme given that they had not participated in the programme.

In carrying out the matching of the characteristics of the treatment and the control group, some matching techniques were suggested in the literature. However, for this study, we employed the radius matching technique because of some merits it has over other matching techniques.

The first procedure for PSM is to obtain the propensity score. However, this involves the matching of the characteristics of the treatment group for men/women entrepreneurs with the characteristics of the control group so that men/women with the same covariate or observable characteristics can be selected. For this purpose, the probit model was used to calculate the propensity score. 


\section{Result and Discussion}

\section{a) Descriptive Statistics}

From the descriptive statistic result in Table 1, less than half of the male entrepreneurs participated in the credit programme. This is represented by the frequency and percentage of 67 (35.08\%) respectively and the remaining $124(64.92 \%)$ representing the frequency and percentage did not participate in the credit programme. However, for the female entrepreneurs, more than half participated in the credit programme as indicated by the percentage and frequency of $50.97 \%$ and 183 respectively. In addition, the remaining frequency 176 and percentage of $49.03 \%$ did not collect any loan.

Among the male entrepreneurs, $64.92 \%$ belong to a political party while the remaining $35.08 \%$ is not a member of any political party. For the female entrepreneurs, $62.40 \%$ participated in one political party or the other and the remaining $37.60 \%$ did not belong to any political party.

Furthermore, over $60 \%$ of the male entrepreneurs are in their active working age group. Also, for the female entrepreneurs, over $70 \%$ are in their active working age. In terms of marital status, more than half (over 50\%) of the male entrepreneurs were married, while over $60 \%$ of the female entrepreneurs were married.

Majority of the female respondents have a formal education and this is represented by $93.87 \%$. Also, this falls in the area of primary level of education, secondary level of education, and ordinary National Diploma level of education while the remaining $6.13 \%$ did not have any formal education. Similarly, majority of the male entrepreneurs are educated. This is represented by $94.76 \%$ and $5.24 \%$ with their level of education fallen in the area of primary, secondary, and Ordinary National Diploma.

Table 1. Descriptive Statistics

\begin{tabular}{lll}
\hline Variables & Frequency & Percentage (\%) \\
\hline Gender & & \\
Male & 191 & 34.73 \\
Female & 359 & 65.27 \\
Treat & & \\
Male - & & \\
Treated & 67 & 35.08 \\
Untreated & 124 & 64.92 \\
Female- & & \\
Treated & 183 & 50.97 \\
Untreated & 176 & 49.03 \\
Mem_political & & \\
Male- & & \\
Member & 124 & 64.92 \\
Non-member & 67 & 35.08 \\
Female- & & \\
Member & 224 & 62.40 \\
Non-member & 135 & 37.60 \\
\hline
\end{tabular}




\begin{tabular}{lll}
\hline $\begin{array}{l}\text { Age group } \\
\text { Male }\end{array}<$ & \\
$<=25$ & 16 & 8.36 \\
$26-35$ & 84 & 43.98 \\
$36-45$ & 45 & 23.56 \\
$46-55$ & 34 & 17.80 \\
$56-65$ & 12 & 6.28 \\
Female & & \\
$<=25$ & 62 & 17.27 \\
$26-35$ & 223 & 62.12 \\
$36-45$ & 31 & 8.64 \\
$46-55$ & 6 & 1.67 \\
$56-65$ & 37 & 10.31 \\
Marital Status & & \\
Male - & & \\
Single & 84 & 43.98 \\
married & 107 & 56.02 \\
Female - & & \\
Single & 136 & 37.88 \\
Married & 223 & 62.12 \\
Education & & \\
Male - & & \\
No formal education & 10 & 5.24 \\
Formal education & 181 & 94.76 \\
female - & & \\
No formal education & 22 & 6.13 \\
Formal education & 337 & 93.87 \\
\hline
\end{tabular}

\section{Propensity Score Matching (PSM) Results}

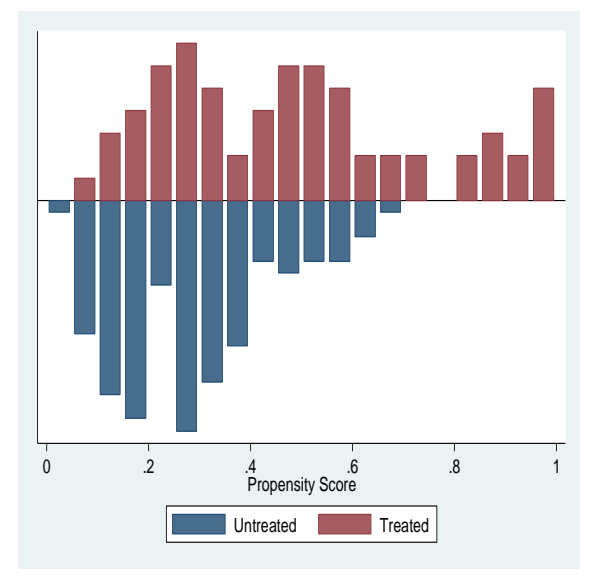

Figure 1. The Distribution of the conditioning 


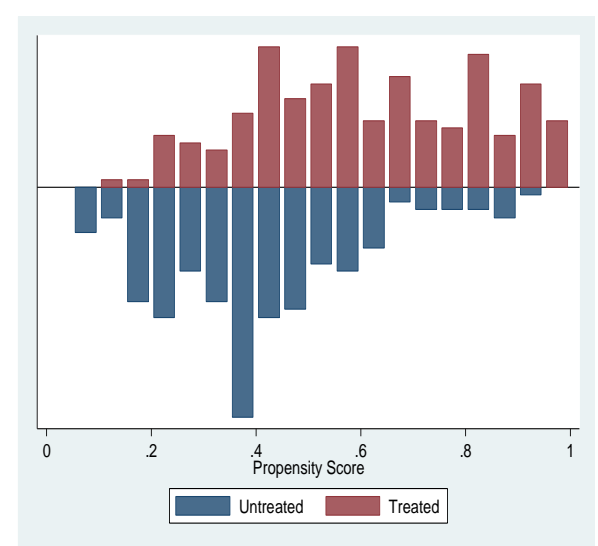

Figure 2. The Distribution of the conditioning probability for Male probability for Female

The Figure 1 above shows the distribution of the propensity score for the matched sample (treated and control observation). From this figure, it is observed that the distribution of the conditioning covariate is equal across the treatment and control observation for men/women entrepreneurs in the matched sample. This indicates that the balancing property has been satisfied.

Furthermore, Table 2 below shows the matching quality before the matching and after the matching was done. From the table, it can be observed that there are no pretreatment differences between the treated observation and the control observation for both male and female entrepreneurs from the $\mathrm{P}$ value matched as shown by column 3 in the table.

Table 2. Indicators of the Matching Quality before and After matching

\begin{tabular}{llllll}
\hline Samples & $\begin{array}{l}\text { P-value: } \\
\text { Unmatched }\end{array}$ & Matched & $\begin{array}{l}\text { Mean bias (\%): } \\
\text { Unmatched } \\
\text { Matched }\end{array}$ & $\begin{array}{l}\text { Mean bias } \\
\text { Reduction } \\
((\%)\end{array}$ \\
\hline $\begin{array}{l}\text { Male } \\
\text { Entrepreneurs }\end{array}$ & 0.000 & 0.111 & 31.6 & 16.0 & 49 \\
$\begin{array}{l}\text { Female } \\
\text { Entrepreneurs }\end{array}$ & 0.000 & 0.208 & 35.1. & 12.2 & 65 \\
\hline
\end{tabular}

Also, from the table, it can be observed that there was a substantial fall in the mean bias after the matching had been completed for both male and female entrepreneurs. Thus, the mean bias of the covariates $\mathrm{X}$ for both samples falls below the $20 \%$ as advised by Rosembaum and Rubin (1985). This indicates that the self-selection bias has been eliminated and the matching criteria have been satisfied. 
Table 3. Average Treatment Effect (ATT) - Radius Matching

\begin{tabular}{|c|c|c|c|c|c|c|}
\hline Sample & $\begin{array}{l}\text { Outcome } \\
\text { Variable }\end{array}$ & $\begin{array}{l}\text { ATT } \\
(\mathrm{NGN})\end{array}$ & $\begin{array}{l}\text { Treated } \\
\text { on support } \\
\text { support }\end{array}$ & Off- & $\begin{array}{l}\text { Control } \\
\text { on support } \\
\text { support }\end{array}$ & Off- \\
\hline $\begin{array}{l}\text { Male } \\
\text { Entrepreneurs }\end{array}$ & Pr_af_loan & $12878.21 * * *$ & 52 & 15 & 117 & 7 \\
\hline $\begin{array}{l}\text { Female } \\
\text { Entrepreneurs }\end{array}$ & Pr_af_loan & $6144.24 * *$ & 172 & 11 & 168 & 8 \\
\hline
\end{tabular}

Significant at $1 \% * * * 5 \% * *, 10 \% *$, NGN Naira amount, Pr_af_loan Profit after the collection of loan

The result of the Average Treatment effect on the Treated (ATT) was done with Radius matching technique and this is presented in Table 3 above. This result indicates that participation in microcredit has a highly significant and positive effect on the business growth of both male and female entrepreneurs in the study area. For the male entrepreneurs, the ATT result shows that those that accessed credit have on the average a higher growth on their profit of NGN 12878.21 than those entrepreneurs that did not access the credit facility.

Similarly, for the female entrepreneurs, the estimates from the ATT indicates that those that participated in the microcredit programme have on the average a significant and higher growth on their profit of NGN 6144.24 than those who did not participate in the credit programme.

These findings depict that entrepreneurs that participated in the microcredit programme are better off in their earning on profit than those who did not partake in the programme for both male and female. Therefore, our result is consistent with the findings of Yadessa, Jina, and Akessa (2015) and Ferdousi (2015).

Table 3. Treatment Effect: Sensitivity Analysis of Matching Algorithms

Neighbor Matching

\begin{tabular}{|c|c|c|c|c|c|c|}
\hline Sample & $\begin{array}{l}\text { Outcome } \\
\text { Variable }\end{array}$ & $\begin{array}{l}\text { ATT Result } \\
\text { (NGN) }\end{array}$ & $\begin{array}{l}\text { Treated: } \\
\text { On support o } \\
\text { support }\end{array}$ & & $\begin{array}{l}\text { Control: } \\
\text { On support } \\
\text { support }\end{array}$ & off \\
\hline $\begin{array}{l}\text { Male } \\
\text { Entrepreneurs }\end{array}$ & Pr_af_loan & $5653.73 * *$ & 67 & - & 124 & - \\
\hline $\begin{array}{l}\text { Female } \\
\text { Entrepreneurs }\end{array}$ & Pr_af_loan & $\begin{array}{l}\text { 4995.08* } \\
\text { Kernel } \\
\text { Matching }\end{array}$ & 183 & - & 176 & - \\
\hline $\begin{array}{l}\text { Male } \\
\text { Entrepreneurs }\end{array}$ & Pr_af_loan & $11044.78^{* *}$ & 67 & - & 124 & - \\
\hline $\begin{array}{l}\text { Female } \\
\text { Entrepreneurs }\end{array}$ & Pr_af_loan & $1778.69 * *$ & 183 & - & 176 & - \\
\hline
\end{tabular}

Significant at 1\%*** 5\%**, 10\%*, NGN Naira amount, Pr_af_loan Profit after the collection of loan 
Furthermore, to verify if the result of the radius matching technique used by the study is robust than other matching techniques, sensitivity analysis was carried out with the use of neighbor and Kernel matching technique for both male and female entrepreneurs. The estimates from the sensitivity analysis in Table 3 above reveals that radius matching method is better, robust, and insensitive to other matching techniques (neighbor and Kernel). Though the result of the radius matching method is higher than the two other matching methods, nevertheless, the result is however in line with other methods of matching techniques.

\section{Conclusion and Recommendation}

Based on the findings from our results, it is therefore concluded that financial inclusion through access to microcredit programme has significantly increased the profit of both male and female entrepreneurs and have enhanced business growth in the study area. It is, therefore, recommended that more attention should be focused on microfinance programme by policymakers and the government. This is because it has the potential of improving the business status of entrepreneurs so that sustainable growth and development can be achieved in the area of entrepreneurship development. Also, it helps to stimulate employment and reduce poverty.

\section{Suggestions for Further Research}

It is advised that further studies should be conducted to examine other geographical areas in Lagos State to verify if these results can be obtained. Also, further research could also delve into anecdotal evidence to make the result more robust.

\section{References}

1. Babagana, S. A. (2010). Impact assessment of the role of microfinance banks in promoting small and medium enterprises growth in Nigeria. International Journal of Economic Development Research and Investment, 1(1).

2. Becker, S. O., \& Ichino, A. (2002). Estimation of Average Treatment Effects Based on Propensity Scores: The Stata Journal, 2(4); 1-19.

3. CBN (2012). Microfinance Policy, Regulatory and Supervisory Framework for Nigeria (Revised), Abuja: Central Bank of Nigeria.

4. Copestake, J., Bhalotra, S., \& Johnson, S. (2001). Assessing the impact of microcredit: A Zambian case study. Journal of Development Studies, 37(4), 81-100.

5. EFInA (Enhancing Financial Innovation and Access) (2012). Access to Financial Services in Nigeria 2012 Survey. http://www.efina.org.ng/assets/ResearchDocuments/2013- 
Documents/EFInA-Access-to-Financial-Services-in-Nigeria-2012surveyKey-Findings2.pdf

6. EFInA (Enhancing Financial Innovation and Access) (2014). Access to Financial Services in Nigeria 2014 Survey.

http://www.efina.org.ng/assets/Documents/EFInA-Access-toFinancial-Services-in-Nigeria-2014-Survey-Key-Findings.pdf

7. EFInA (Enhancing Financial Innovation and Access) (2016). EFInA Access to Financial Services in Nigeria (A2F) 2016 Survey. http://www.efina.org.ng/assets/A2F/2016/Key-Findings-A2F2016.pdf

8. Ferdousi, F. (2015). Impact of microfinance on sustainable entrepreneurship development, Development Studies Research, 2(1), 51-63.

9. Gichuki, C.N., Mulu-mutuku, M., \& kinithua, N. J. (2014). Performance of women owned enterprises accessing credit from village credit and savings associations in Kenya Journal of Global Entrepreneurship Research. https://doi.org/10.1186/s40497-0140016-1

10. Idowu, A. O., \& Oyeleye, O.A. (2012). Impact of Microfinance Banks on Poverty Alleviation in selected Local Government Areas of Oyo State, Nigeria. European Journal of Business Management, 4 (21).

11. Ike, P. C. (2012). Access to microfinance services and its effect on business performance of small-scale women entrepreneurs in Enugu State, Nigeria. Revista Científica UDO Agrícola 12(4), 899-905.

12. Laetitia, M., Shukla, J., \& Luyanda, A. (2015). Microfinance and business growth of women small and medium enterprises in Rwanda. (a case of selected women small and medium enterprises in kicukiro district). European Journal of Accounting, Auditing and Finance Research, 3(11), 26-39.

13. Mayoux, L. \& Hartl, M. (2009). Gender and rural microfinance: reaching and empowering women. International Fund for Agricultural and Development (IFAD): Rome.

14. Michelle, L., \& Chapman, Z. (2014). Impact of microfinance on entrepreneurial activity in emerging economics: Panel data from Argentina, Brazil, Colombia \& South Africa. International Journal of Entrepreneurship, 18, 59-57.

15. Ngugi. W. V \& Kerongo, F. (2014). Effects of Micro-Financing on Growth of Small and Micro Enterprises in Mombasa County. International Journal of Scientific Engineering and Research (IJSER). 2 (4). 
16. Olusanya, S.O., Sufian, B. J., \& Temi, O. (2014) Can microfinancing improve small and medium scale enterprises in Lagos State, Nigeria? Journal of Economics and Finance, 3(3), 49-56.

17. Rathirance $\&$ Semassinghe (2016). The impact of microfinance on women entrepreneurs' performance in North Srilanka. International Journal of Social Science Studies 4(3), 94-99.

18. Rosenbaum, P. R., \& Rubin, D. B. (1985). Constructing a control group using multivariate matched sampling methods that incorporate the propensity score. The American Statistician, 39(1), 33-38.

19. Wang, X. (2013). The Impact of Microfinance on the Development of Small and Medium Enterprises: The Case of Taizhou, China, The Johns Hopkins University, Baltimore, MD: USA.

20. Wilfred, N. K., Max, A., Omeke, M., Norman, T., \& Moses, N. (2015). The impact of microfinance service delivery on the growth of SNEs in Uganda. International Journal of Economics, Commerce and Management, 3(5), 229-237.

21. Wooldridge, J. (2002). Econometrics analysis of cross section and panel data. Cambridge. MA USA: MIT Press.

22. World Bank (2012). Financial inclusion strategies. Reference frame work:

23. Washington DC; USA

24. World Bank (2013). Global financial Development report. Washington DC; World Bank

25. World Bank (2014). Global financial Development report 2014: Financial inclusion. The World Bank, Washington DC: USA.

26. Yadessa, Jina \& Akessa (2015).Global Journal of Management and Business Research: B Economic and Commerce 15(6). 